\title{
Low Expression of p27 Protein Combined with Altered p53 and Rb/p16 Expression Status Is Associated with Increased Expression of Cyclin A and Cyclin B1 in Diffuse Large B-Cell Lymphomas
}

\author{
Maria Bai, M.D., John Vlachonikolis, Ph.D., Niki J. Agnantis, M.D., Ph.D., Elena Tsanou, M.D., \\ Sofia Dimou, M.D., Constatinos Nicolaides, M.D., Stella Stefanaki, M.D., Nicolaos Pavlidis, M.D., Ph.D., \\ Panagiotis Kanavarous, M.D., Ph.D. \\ Departments of Pathology (MB, NJA, ET, SD, SS) and Oncology (CN, NP), Medical Faculty, University of \\ Ioannina, Ioannina; Department of Biostatistics, Medical Faculty, University of Crete (JV), Crete; and \\ Department of Histology, Medical Faculty, University of Thessallia (PK), Greece
}

The expression of the cyclin-dependent kinase inhibitor (CDKI) p27 protein was investigated in relation to (1) the expression of the cell cycle regulators $\mathrm{p53}, \mathrm{Rb}$ and p16 and (2) the proliferation profile as determined by the expression of Ki67, cyclin A, and cyclin $\mathrm{B} 1$ in 80 cases of de novo diffuse large B-cell lymphomas (DLBCL). P27 expression was low/null in large tumor cells in 58/80 cases and intermediate/high in 22/80 cases. Increased expression of p53 protein was observed in 39/80 cases. Decreased expression of $\mathrm{Rb}$ and p16 proteins was mutually exclusive and was observed in $5 / 80$ and $14 / 80$ cases, respectively. The analysis of the p27 expression status (low/null versus intermediate/high) with respect to the $\mathrm{p53}$ and/or Rb/p16 expression status showed that low/null p27 expression was significantly correlated with increased p53 expression $(P=.018)$ and showed a strong trend for correlation with concurrent increased p53 expression and decreased $R b$ or p16 expression $(P=.050)$. These findings suggest a tendency for concurrent alterations of the cell cycle regulators p27, p53, and Rb or p16 in DLBCL, which might result in impaired tumor growth control. Indeed, the analysis of the combined p27/p53/ $\mathrm{Rb} / \mathrm{p} 16$ expression status with respect to the proliferation profile showed that (1) three alterations in the combined $\mathrm{p} 27 / \mathrm{p} 53 / \mathrm{Rb} / \mathrm{p} 16$ status (i.e., low/null P27 expression, increased expression of p53, and decreased expression of $\mathrm{Rb}$ or p16) were significantly correlated with increased expression of cyclin $B 1(P=.005)$ and $(2)$ two or three alterations were significantly correlated with increased expression of cyclin A $(P=.014)$. These findings suggest combined impairment of a complex cell-cycle control

Address reprint requests to: Maria Bai, Department of Pathology, Medical Faculty, University of Ioannina, 45110, Ioannina, Greece; fax: 0651-97858. network involving the CDK inhibitor p27, the P53 pathway, and the Rbl pathway, which exerts a cooperative effect resulting in enhanced tumor cell proliferation.

KEY WORDS: B-cell lymphoma, Cell cycle, Immunohistochemistry.

Mod Pathol 2001;14(11):1105-1113

Cell cycle progression is regulated by a complex molecular network involving cyclins, cyclindependent kinases (CDK) and CDK inhibitors (CDKIs; 1-6). Cyclins are divided in two main families $(1,2,6)$. The G1 family includes cyclins C, D1-3, and E, which are important for the passage of cells through the G1 phase and their entry into the S-phase. The other family includes the cyclins A and B. Cyclin A is involved in DNA replication in the S-phase while cyclins B1 and B2 ensure irreversible entry into mitosis. The activity of the cyclin-CDK complexes is negatively regulated by the CDKIs (1, $2,6)$. There are two known families of CDKIs. The INK4 inhibitors (p16/INK4A, p15/INK4B, p18/ INK4C, and p19/INK4D) are specific for CDK4 and 6, while the CIP/KIP inhibitors (p21/CIP1, p27/KIP1 and P57/KIP2) target a broader spectrum of CDKs including CDK2, 4 and 6, and possibly CDK1 (4-6).

The p53 pathway and the Rb1 pathway are two major growth regulatory pathways $(3,6)$. The p53 pathway regulates apoptosis and cell cycle arrest in G1 phase, depending on the cell type and cell state. P53-dependent G1 arrest is mediated, at least in part, through p53-mediated induction of p21 (3). The activity and the stability of p53 protein is regulated via interactions with proteins such as mdm2 which allows targeting of p53 to the ubiquitinmediated proteolytic network. The Rbl pathway inhibits transcription of genes necessary for the 
transition from G1 to S phase (6). Central to this pathway is the regulation of phosphorylation of the $\mathrm{Rb}$ protein $(\mathrm{pRb})$. Hypophosphorylated $\mathrm{pRb}$ binds and inactivates transcription factors, notably the E2F1, important for the transition from G1 to S phase. When pRb is phosphorylated the E2F1 transcription factor is released. Phosphorylation of $\mathrm{pRb}$ is stimulated by cyclinD-CDK4/6 complexes and inhibited by the p16 and other CDKIs including p27 $(3,6)$. Recent evidence has linked the two pathways through the 9p21 locus in which reside two CDKI genes, the CDKN2A and CDKN2B genes $(2,3,6)$. The CDKN2A gene encodes p16 protein which is involved in the RB1 pathway whereas the p14/ARF protein binds to $\mathrm{mdm} 2$ and promotes $\mathrm{mdm} 2 \mathrm{deg}$ radation thereby abrogating the mdm2-mediated degradation of p53 $(3,6)$. A simplified overview of the aforementioned various cell cycle interactions is summarized in Figure 1.

Diffuse Large B-cell Lymphomas (DLBCL) (7) represent the most common type of non-Hodgkin's lymphomas in Western countries (8) and are characterized by heterogeneous clinical, immunophenotypic and genetic features (7-9). Reflecting their biological heterogeneity, alterations of several cell cycle regulators have been identified in DLBCL (10$39)$. Frequent alterations include p53 protein overexpression, sometimes associated with p53 gene mutations, mdm2 overexpression and p16 protein underexpression, mainly associated with CDKN2A gene deletion or hypermethylation while $\mathrm{Rb}$ protein reduced expression and $\mathrm{Rbl}$ gene alterations appear to be infrequent $(10-14,17-24,28-32)$. There is increasing recent evidence that reduced expression of the CDK inhibitor p27 may have important pathogenetic implications in malignancies because of its association with histological aggressiveness and poor clinical outcome $(4,5,15,18,25,34)$. Moreover, the importance of reduced p27 expres-

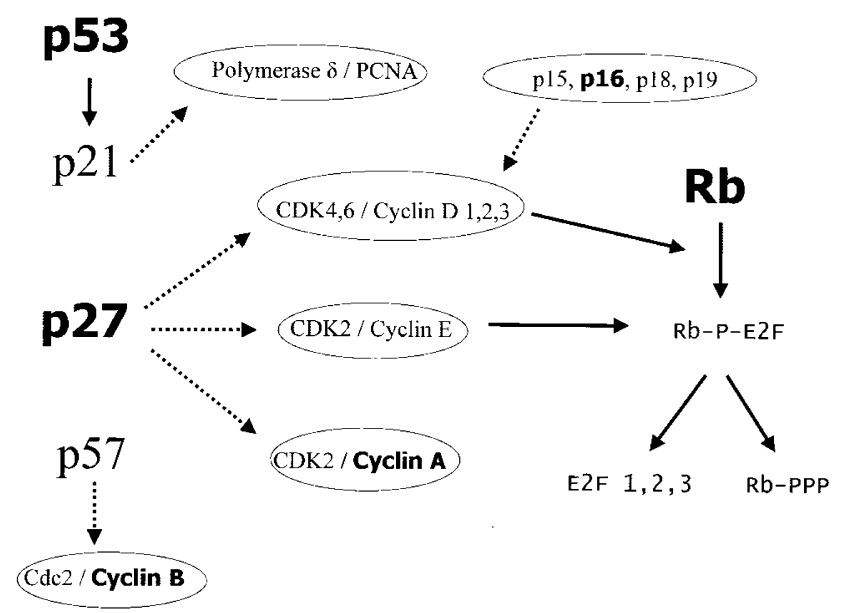

FIGURE 1. Linear arrow: induction; nonlinear arrow: inhibition. The molecules studied are indicated in bold. sion in neoplastic progression is underscored by the fact that p27 heterozygous and nullizygous mice are tumor prone when challenged with carcinogenic stimuli (40). Furthermore, reduced p27 expression combined with alterations in the status of $\mathrm{Rb}$ or p53 may have cooperative effects resulting in uncontrolled tumor cell proliferation and aggressive malignancies in experimental mouse models and in humans $(41,42)$. In normal cells p27 is expressed when cells are arrested in G0/G1 phases, the levels of this protein declining as the cells progress to $S$ phase $(4,5)$. In normal lymphoid tissue, p27 is expressed in non-proliferating lymphocytes, whereas proliferating lymphoid cells within germinal centers are often negative (16). In lymphomas, when all histological types are taken into consideration, this relationship between p27 expression and proliferation is generally preserved, with an inverse expression of p27 and Ki67 proteins $(15,16,18,25,34)$. Aggressive lymphomas including DLBCL, Burkitt's lymphoma, and mantle cell lymphoma generally display low or null expression of p27 protein and high proliferative activity, suggesting that down-regulation of p27 may be involved in the impaired tumor growth control $(15,16,18,25$, 34). Nevertheless, cases of DLBCL and Burkitt's lymphoma with concurrent high p27 and Ki67 expression were also reported $(16,37)$. This association was recently attributed to the existence of $\mathrm{p} 27$ / cyclinD3 complexes, which could lead to anomalous p27 stabilization, probably associated with its functional inactivation (26).

The above data indicate complex implication of p27 in the regulation of the cell cycle in DLBCL. In order to gain further insight in the role of p27 in tumor growth regulation of DLBCL, we have investigated the expression of p27 in relation to (1) the expression status of the major cell cycle regulators $\mathrm{p} 53, \mathrm{Rb}$, and p16 and (2) the proliferation profile as determined by the expression of Ki67, cyclin A, and cyclin B1 proteins. Moreover, we have also evaluated the impact of combined alterations in the p27/ $\mathrm{p} 53 / \mathrm{Rb} / \mathrm{p} 16$ expression status on the proliferation profile.

\section{MATERIALS AND METHODS}

\section{Materials}

Eighty cases of de novo diffuse large B-cell lymphomas (37 nodal and 43 extranodal) classified according to the REAL classification (6) were selected from the files of the Department of Pathology of the University of Ioannina on the basis that complete clinicopathological parameters were available. Reactive lymphoid tissues including lymph nodes and tonsils were used as control. 


\section{Immunohistochemistry}

Immunostainings were performed on formalinfixed, paraffin-embedded tissue sections by the labeled streptavidin avidin biotin (LSAB) method. A step of microwave pretreatment was used as described previously (43). Monoclonal antibodies directed against p53 protein (DO-7, Dako SA, Glostrup, Denmark, dilution 1:50), Rb protein (Rb1, Dako SA dilution 1:20), proliferation-associated nuclear antigen Ki67 (MIB-1, Immunotech, Marseille, France; dilution 1:20), cyclin A (6E6, Novocastra, Newcastle upon Tyne, dilution 1:10), cyclin B1 (7A9, Novocastra, dilution 1:10), p16 (F-12, Santa Cruz Biotechnology, USA, dilution 1:100), and p27 (IB4, Novocastra, dilution 1:20) were applied. Positive control slides were included in all cases. They consisted of nodal and extranodal non-Hodgkin lymphomas from our previous studies $(14,31,44)$. Moreover, for Rb, p16, p27, cyclin A, cyclin $B_{1}$ and Ki67 internal positive control was required. For evaluation of immunostaining, a continuous score system was adopted by using the $40 \times$ objective lens and counting at least 5 fields selected on the basis that they contained immunopositive cells. The number of immunopositive cells was divided by the total number of the counted cells, and the expression was defined as the percentage of positive cells in the total number of the counted cells. P53increased expression was considered when the expression of this protein in tumor cells was higher than the maximum value of the expression in lymphoid cells in the reactive lymphoid tissues $(7 \%)$. $\mathrm{Rb}$ - or p16-decreased expression (partial or total) was considered, as described previously (19), when the tumor cells were negative and interspersed nuclei of reactive cells (small lymphocytes, endothelial cells) were positive and were used as internal positive controls. On that basis, positive p53 and negative $\mathrm{Rb}$ or p16 expression status was considered the increased P53 and the decreased Rb or p16 expression, respectively (Table 1). Low/null p27 expression in large tumor cells in DLBCL was considered, as described previously (26), when the range of this expression was comparable to that observed in large lymphoid cells of the reactive lymphoid tissues (0 to $6 \%$ ).

TABLE 1. Expression Patterns of p53 and/or Rb/p16 Proteins

\begin{tabular}{lc}
\hline \multicolumn{1}{c}{ Patterns } & Number of Cases \\
\hline $\mathrm{p} 53-$ & $41 / 80$ \\
$\mathrm{p} 53+$ & $39 / 80$ \\
$\mathrm{Rb}+/ \mathrm{p} 16+$ & $61 / 80$ \\
$\mathrm{Rb}-/ \mathrm{p} 16+$ & $5 / 80$ \\
$\mathrm{Rb}+/ \mathrm{p} 16-$ & $14 / 80$ \\
$\mathrm{P} 53+/ \mathrm{Rb}-/ \mathrm{p} 16+$ & $4 / 80$ \\
$\mathrm{P} 53+/ \mathrm{Rb}+/ \mathrm{p} 16-$ & $9 / 80$ \\
\hline
\end{tabular}

Statistical Analysis

Pearson's and Spearman's correlation coefficients were used for the assessment of correlation between continuous variables. The correlation between p27 and the p53 and/or Rb/p16 expression status was analyzed by chi-square test, and the strength of the association was further studied by the relative risk (RR) and the 95\% confidence interval (CI; Table 2). The analysis of variance (ANOVA), the Student-Newman-Keuls procedure for post hoc multiple comparison tests, and the multiple analysis of variance (MANOVA) were used to correlate the combined $\mathrm{p} 27 / \mathrm{p} 53 / \mathrm{Rb} / \mathrm{p} 16$ patterns with the expression of Ki67, cyclin A, and cyclin B1 (Table 3). The results were considered statistically significant when $P<.05$. The program SPSS for Windows, Release 8, was used for statistical analysis.

\section{RESULTS}

Expression of p27, p53, Rb, and p16 proteins and proliferation profile

P27 expression in large tumor cells ranged from 0 to $34 \%$. P27 expression was low/null (0 to $6 \%$ ) in $58 / 80$ cases and intermediate/high (6 to $34 \%$ ) in 22/80 cases (Fig. 2). P53, Rb, and p16 expression in large tumor cells ranged from 0 to $95 \%, 31$ to $90 \%$, and 37 to $94 \%$, respectively. Increased expression of p53 protein was observed in 39/80 cases (Table 1). Decreased expression of $\mathrm{Rb}$ and $\mathrm{p} 16$ proteins was mutually exclusive and was observed in 5/80 and 14/80 cases, respectively (Table 1 ). Combined p53/ $\mathrm{Rb} / \mathrm{p} 16$ altered expression status was observed in 13/80 cases (Table 1 ). Ki67, cyclin A, and cyclin B1 expression (Figs. 3 and 4) was found in all cases (Table 3). P27 did not show significant correlations with p53, Rb, p16, Ki67, cyclin A, or cyclin B1 when these expressions were compared as continuous variables using Pearson's and Spearman's correlation coefficients. However, when the expression status of p27 (low/null versus intermediate/high) was correlated with the $\mathrm{p} 53$ and/or $\mathrm{Rb} / \mathrm{p} 16$ expression status (Table 2), it was observed that low/null p27 expression was significantly correlated with p53+ pattern $\left(\chi^{2}=5.062\right.$, df $\left.=1, P=.018\right)$ and showed a strong trend for correlation with combined alterations (p53 $+/ \mathrm{Rb}-/ \mathrm{p} 16+$ or $\mathrm{p} 53+/ \mathrm{Rb}+/$ p16- patterns) ( $\chi^{2}=3.732$, df $\left.=1, P=.050\right)$ but not with $\mathrm{Rb}-/ \mathrm{p} 16+$ or $\mathrm{Rb}+/ \mathrm{p} 16-$ patterns $\left(\chi^{2}=1.714\right.$, $\mathrm{df}=1, P=.190)$. The risk of low/null p27 among observations with $\mathrm{p} 53+$ pattern was 1.4 times that of observations with p53- pattern $(\mathrm{RR}=1.387 ; 95 \%$ $\mathrm{CI}=1.049,1.835$; Table 2). The risk of low/null p27 among observations with $\mathrm{Rb}-/ \mathrm{p} 16+$ or $\mathrm{Rb}+/ \mathrm{p} 16-$ patterns was 1.2 times that of observations with $\mathrm{Rb}+/ \mathrm{p} 16+$ pattern $(\mathrm{RR}=1.222 ; 95 \% \mathrm{CI}=0.945$, 1.582; Table 2). The risk of low/null p27 among 


\begin{tabular}{|c|c|c|}
\hline Patterns & P27 & P27 \\
\hline p53 patterns ${ }^{a}$ & intermediate/high & low/null \\
\hline $\mathrm{P} 53-$ & 16 cases & 25 cases \\
\hline $\mathrm{P} 53+$ & 6 cases & 33 cases \\
\hline $\mathrm{Rb} / \mathrm{p} 16$ patterns ${ }^{b}$ & intermediate/high & low/null \\
\hline $\mathrm{Rb}+/ \mathrm{p} 16+$ & 19 cases & 42 cases \\
\hline $\mathrm{Rb}-/ \mathrm{p} 16+$ or $\mathrm{Rb}+/ \mathrm{p} 16-$ & 3 cases & 16 cases \\
\hline p53 and $\mathrm{Rb} / \mathrm{p} 16$ patterns ${ }^{c}$ & intermediate/high & low/null \\
\hline Combined alterations $(\mathrm{p} 53+/ \mathrm{Rb}-/ \mathrm{p} 16+$ or $\mathrm{P} 53+/ \mathrm{Rb}+/ \mathrm{p} 16-)$ & 1 case & 12 cases \\
\hline Absence of combined alterations & 21 cases & 46 cases \\
\hline
\end{tabular}

${ }^{a} \chi^{2}=5.062, \mathrm{df}=1, \mathrm{P}=.018 . \mathrm{RR}=1.387 ; 95 \% \mathrm{CI}=1.049,1.835$.

${ }^{b} \chi^{2}=1.714, \mathrm{df}=1, \mathrm{P}=.190$ (not significant). $\mathrm{RR}=1.222 ; 95 \% \mathrm{CI}=0.945,1.582$.

${ }^{c} \chi^{2}=3.732, \mathrm{df}=1, \mathrm{P}=.050 . \mathrm{RR}=1.344 ; 95 \% \mathrm{CI}=1.073,1.684$.

Df, degrees of freedom; RR, relative risk; CI, confidence interval.

TABLE 3. Combined p27/p53/Rb/p16 Expression Patterns in Relation to the Mean Values of the Expression of Ki67, Cyclin A, and Cyclin B1

\begin{tabular}{lccc}
\hline Groups & Number of Cases & $\begin{array}{c}\text { Ki67 (\%) } \\
\text { Mean Value } \pm \text { SD }\end{array}$ & $\begin{array}{c}\text { Cyclin A (\%) } \\
\text { Mean Value } \pm \text { SD }\end{array}$ \\
\hline 0 & 12 & $48.33 \pm 21.56$ & $20.83 \pm 16.35$ \\
1 & 35 & $62.57 \pm 18.52$ & $31.62 \pm 16.67$ \\
2 & 22 & $56.59 \pm 23.97$ & $37.27 \pm 20.80$ \\
3 & 11 & $66.81 \pm 21.36$ & $45.45 \pm 21.96$ \\
Totals & 80 & $59.37 \pm 21.35$ & $33.46 \pm 19.63$ \\
\hline
\end{tabular}

Group 0 is composed of simultaneous absence of low p27 expression, absence of increased p53 expression, and absence of decreased Rb or p16 expression (no alteration: 12 cases). The group 1 is composed of low/null p27 expression or of increased p53 expression or decreased Rb or p16 expression (one alteration: 35 cases). Group 2 is composed of low/null p27 expression with increased p53 expression or of low/null p27 expression with decreased $\mathrm{Rb}$ or p16 expression or of increased p53 expression with decreased Rb or p16 expression (two alterations: 22 cases). Group 3 is composed of simultaneous detection of low/null p27 expression, increased p53 expression, and decreased Rb or p16 expression (three alterations: 11 cases).

observations with combined alterations (p53+/ $\mathrm{Rb}-/ \mathrm{p} 16+$ or $\mathrm{p} 53+/ \mathrm{Rb}+/ \mathrm{p} 16-$ patterns) was 1.3 times that of observations with absence of combined alterations $(\mathrm{RR}=1.344 ; 95 \% \mathrm{CI}=1.073$, 1.684) (Table 2).

\section{Correlations of the Combined p27/p53/Rb/p16 Expression Status with the Proliferation Profile}

The combined $\mathrm{p} 27 / \mathrm{p} 53 / \mathrm{Rb} / \mathrm{p} 16$ expression patterns were compared with respect to the expression of Ki67, cyclin A, and cyclin B1 (Table 3). Four groups $(0,1,2$, and 3$)$ were defined on the basis that low/null p27 expression, increased expression of p53, and decreased expression of Rb or p16 reflect altered cell cycle regulation $(16-18,24,29,34,42$ 46): Group 0 was composed of simultaneous absence of low/null p27 expression, absence of increased p53 expression, and absence of decreased $\mathrm{Rb}$ or p16 expression (no alteration: 12 cases). Group 1 was composed of low/null p27 expression or increased p53 expression or decreased $\mathrm{Rb}$ or $\mathrm{p} 16$ expression (one alteration: 35 cases). Group 2 was composed of low/null p27 expression with increased p53 expression or of low/null p27 expression with decreased $\mathrm{Rb}$ or p16 expression or of increased p53 expression with decreased $\mathrm{Rb}$ or p16 expression (two alterations: 22 cases). Group 3 was composed of simultaneous detection of low/null p27 expression, increased p53 expression, and de- creased $\mathrm{Rb}$ or $\mathrm{p} 16$ expression (three alterations: 11 cases). Using analysis of variance, the differences between the 4 groups were not significant with respect to Ki67 $(F=1.971, \mathrm{df}=3.76, P=.125)$. With respect to cyclin $\mathrm{A}$ and cyclin $\mathrm{B} 1$ the differences were significant $(F=3.755, \mathrm{df}=3.76, P=.014$ and $F=4.669$, $\mathrm{df}=3$, and $P=.005$, respectively). These results were confirmed using the nonparametric Kruskal-Wallis test (Ki67: $P=.164$; cyclin A: $P=$ .011 and cyclin B1: $P=.043)$. The StudentNewman-Keuls procedure confirmed that (1) for cyclin A, Group 0 has significantly lower mean value than Groups 2 and $3(P<.05)$, which have similar mean values, whereas Group 1 occupies an intermediate position that is no significantly different from those of Group 0 or Groups 2 and 3 and that (2) for cyclin B1, Groups 0, 1, and 2 have similar mean values, which are significantly lower than the mean value of Group $3(P<.05)$. Examining all 3 variables simultaneously, that is, forming a vector of dependent variables, multiple analysis of variance produced a Wilks' lambda of 0.746 with associated $F$ value of $3.561(\mathrm{df}=9.180)$, which was also significant $(P<.001)$.

\section{DISCUSSION}

There is increasing evidence that multiparameter immunohistochemical analysis of the complex mo- 


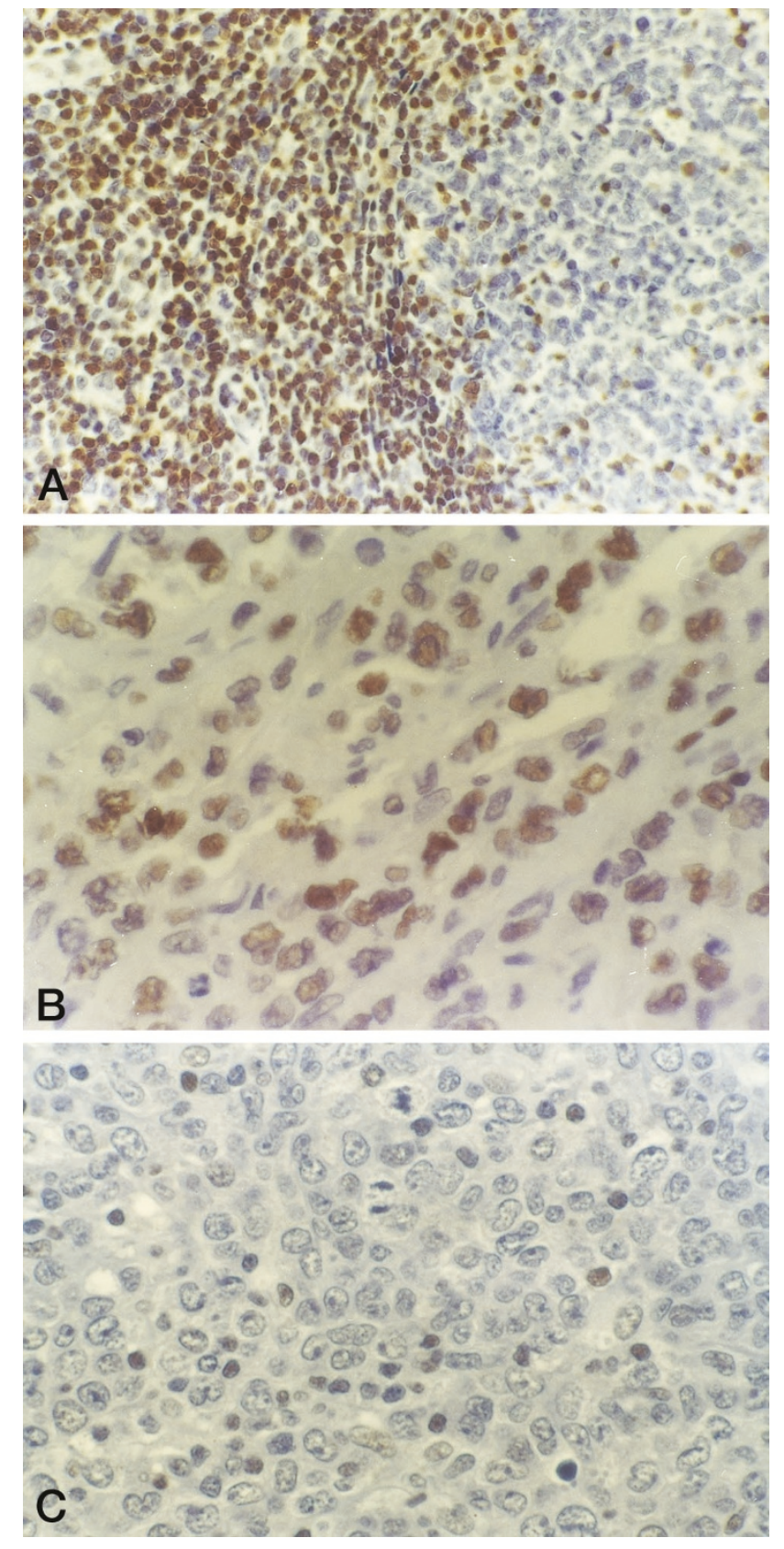

FIGURE 2. A, Low $\mathrm{p} 27$ expression in reactive germinal centers (magnification, $400 \times$ ). B, Intermediate/high p27 expression in tumor cells (magnification, $400 \times$ ). C, Null p27 expression in tumor cells (magnification, $400 \times$ ).

lecular networks regulating the cell cycle in malignancies provides valuable information for the understanding of the impaired regulation of these networks and permits further insight into oncogenesis $(11,15,17,19,23,24,26,29,34,36)$. This approach was adopted in the present study to analyze the expression of $\mathrm{p} 27$ in relation with components of the p53 and Rb1 growth control pathways and the status of proliferation in 80 cases of DLBCL.

In the present study, p27 expression did not show significant correlations with the proliferationrelated proteins Ki67, cyclin A, or cyclin B1. These findings are in keeping with previous results comparing only Ki67 and p27 expression in DLBCL (37) and indicate that in DLBCL, as a whole, the inverse relationship between proliferative activity and p27 expression found in normal lymphoid tissue (16) is lacking. This suggests that p27 down-regulation can represent a genuine aberration in DLBCL. The finding of the present study that about $70 \%$ of DLBCL show low/null p27 expression is in keeping with previous data that down-regulation of p27 expression is very frequent in aggressive lymphoid malignancies (i.e., DLBCL, Burkitt's lymphoma, and mantle cell lymphoma) $(15,16,18,34)$. The reduced levels of p27 protein expression in DLBCL may result from multiple mechanisms. These include enhanced ubiquitin proteasome-mediated protein degradation, which was reported to be the commonest mechanism of reduced p27 expression, reduced mRNA expression or decreased protein translation whereas somatic point mutations or homozygous deletions are very rare (reviewed in 4 and 5). Reduced p27 expression was recently attributed to increased proteasome-mediated protein degradation in mantle cell lymphomas (15), but further studies are needed to clarify if this mechanism also accounts for p27 underexpression in DLBCL. Reduced p27 expression may have important pathogenetic implications in tumor progression because of its association with high-grade epithelial and lymphoid malignancies $(4,5,15,18,25,34)$. Moreover, there is accumulating evidence that concurrent alterations of the status of $\mathrm{p} 27, \mathrm{Rb}$, and $\mathrm{p} 53$ may have cooperative effects resulting in uncontrolled tumor cell proliferation and aggressive malignancies. Indeed, (1) experimental evidence showed that $\mathrm{Rb}(+/-) / \mathrm{P} 27(-/-)$ mice developed pituitary adenocarcinoma with loss of the remaining allele of $\mathrm{Rb}$ and a high-grade thyroid C-cell carcinoma that was more aggressive than the disease in either $\mathrm{Rb}( \pm)$ or $\mathrm{P} 27(-/-)$ mice (41), (2) decreased expression of p27 and overexpression of p53 protein, alone or combined, were predictors of metastatic potential in early invasive colorectal cancer (42), (3) altered p16/INKA4, Rb, and p53 protein status in non-small cell lung carcinomas exert synergistic effect in proliferative activity (45, 46), and (4) concurrent disruption of p16/INKA4 and ARF-p53 pathways was an independent negative prognostic factor in DLBCL, whereas selective disruption of either p16/INKA4 or ARF-p53 pathway did not significantly influence the clinical outcome in that series (32). Because of these aforementioned cooperative effects, we have analyzed (1) the relationship of $\mathrm{p} 27$ with the p53 and $\mathrm{Rb} / \mathrm{p} 16$ expression status and (2) the combined p27/p53/ $\mathrm{Rb} / \mathrm{p} 16$ expression status with respect to the proliferation profile in DLBCL. It was revealed that low/ null p27 expression was significantly correlated 


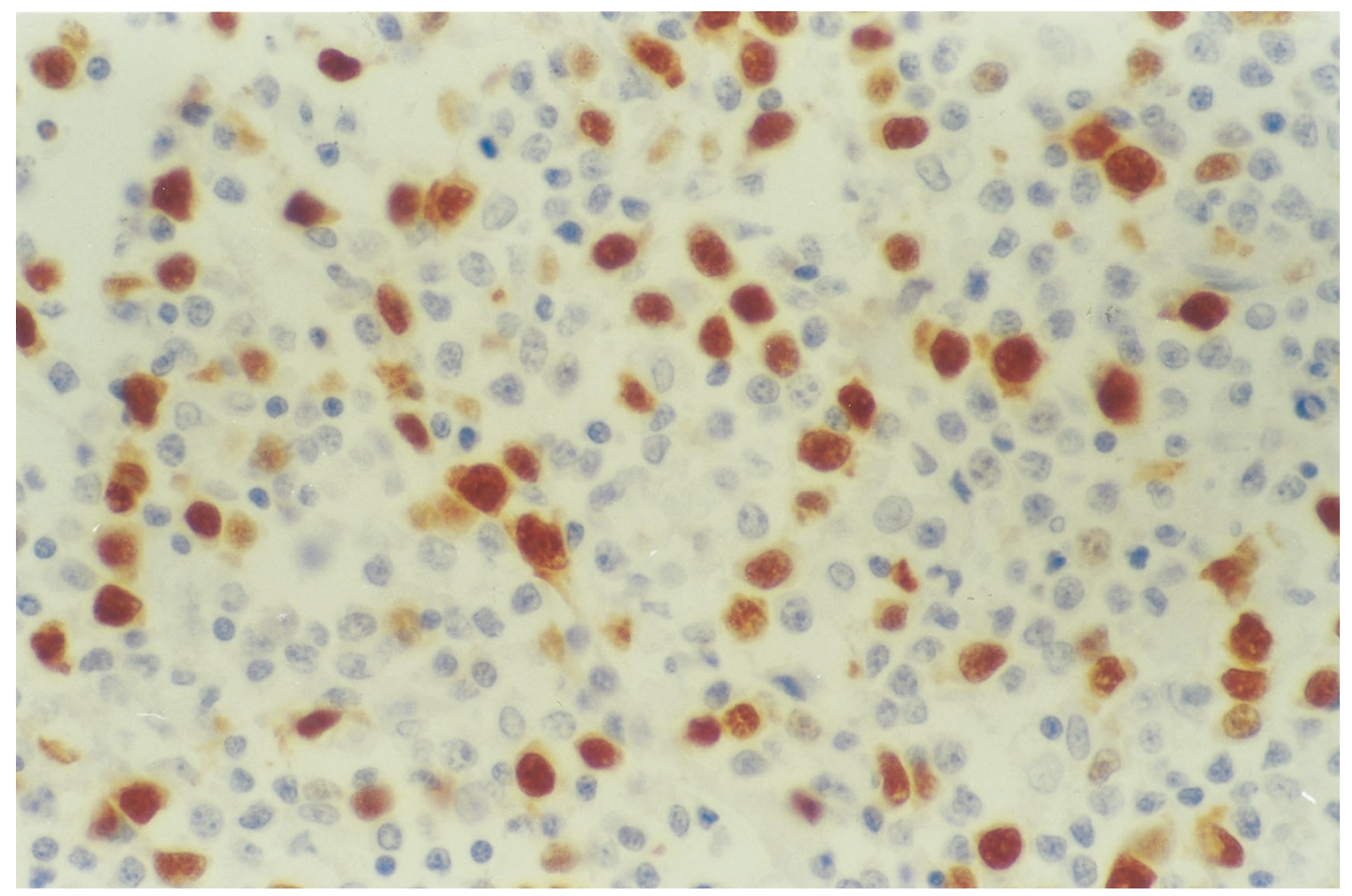

FIGURE 3. Cyclin A expression in tumor cells (magnification, 400×).

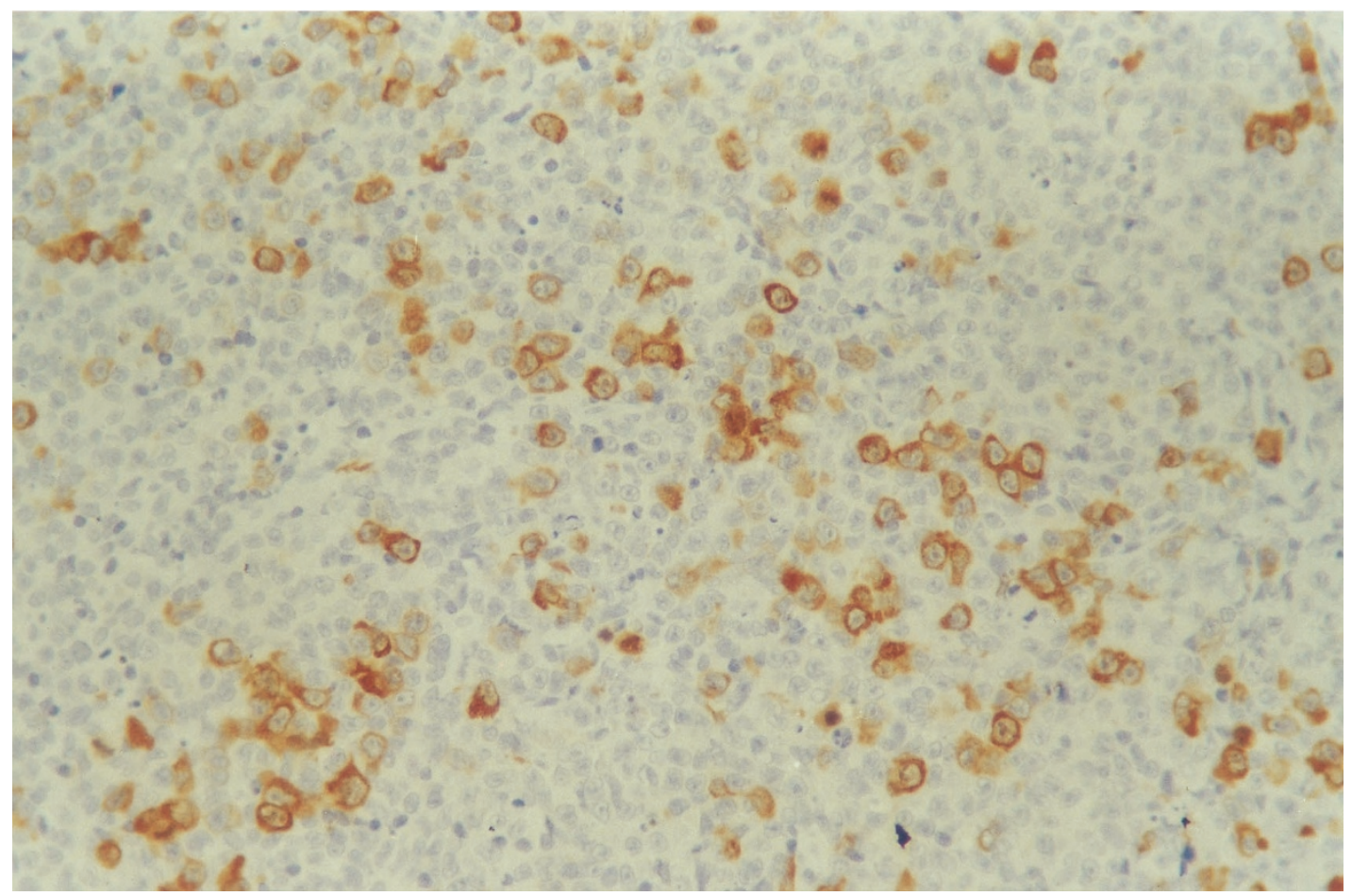

FIGURE 4. Cyclin B1 expression in tumor cells (magnification, 250×).

with increased p53 expression $(P=.018)$ and showed a strong trend for correlation with concurrent increased p53 expression and decreased $\mathrm{Rb}$ or p16 expression $(P=.050)$. This suggests a tendency for concurrent alteration of the cell cycle regulators $\mathrm{p} 27, \mathrm{p} 53$, and $\mathrm{Rb}$ or $\mathrm{p} 16$ in DLBCL. These findings are in keeping with previous immunohistochemical and/or molecular data that concurrent aberrations of p53 and Rb1 pathways are frequent in DLBCL, being reported in about 20 to $40 \%$ of these tumors $(13,24,29,32)$. The concurrent disruption of growth control pathways may have implications in the cell 
cycle by abrogating the compensatory network that was proposed to exist between p53 and Rb1 pathways. According to this proposed model, loss of functional $\mathrm{Rb}$ results in deregulation of the E2F1, which in turn causes stabilization of p53, probably by activating the transcription of ARF $(32,47-49)$. Thus, if both pathways are disrupted and p27 is underexpressed, the control of cell proliferation might be profoundly impaired. Indeed, the analysis of the combined $\mathrm{p} 27 / \mathrm{p} 53 / \mathrm{Rb} / \mathrm{p} 16$ expression status with respect to the proliferation profile showed that 1 ) three alterations in the combined $\mathrm{p} 27 / \mathrm{p} 53 / \mathrm{Rb} / \mathrm{p} 16$ status [i.e., 1) low/null P27 expression, 2) increased expression of p53, and 3) decreased expression of Rb or p16] were significantly correlated with increased expression of cyclin B1 $(P=.005)$; and that 2$)$ two or three alterations were significantly correlated with increased expression of cyclin A $(P=.014)$. The above findings, taken together, suggest combined impairment of a complex cell-cycle control network involving the CDK inhibitor $\mathrm{p} 27$, the $\mathrm{P} 53$ pathway, and the Rb1 pathway, which exerts a cooperative effect resulting in enhanced tumor cell proliferation. To explain the cooperative effects of the impaired p27/p53/Rb/p16 status, the following putative pathogenetic pathways could be suggested: if downregulation of p27 expression occurs, this may permit sequential phosphorylation (inactivation) of pRb by the cyclin D/CDK4,6 and cyclinE/CDK2 complexes, resulting in release of E2F1 from $\mathrm{pRb}$ to activate S-phase entry $(1,2,6)$. Moreover, underexpression of p27 may not disrupt the association between cyclinE/CDK2 and p107/DP1/E2F1 complexes, the formation of which results in transcriptional activation of cyclin A (50). If simultaneous impairment of the p53 pathway also occurs, the ability of p53 to inhibit cyclin/CDK complexes through p21 is deregulated (3). One of the consequences of this impairment is activation of cyclin E/CDK2 complexes, which cause phosphorylation and consequent down-regulation of p27 (51). These events might establish a network linking down-regulation of p27 with impairment in the p53 and Rb1 pathways.

In conclusion, the main finding of the present study was that the simultaneous occurrence of low/ null P27 expression, increased p53 expression, and decreased $\mathrm{Rb}$ or pl6 expression status is strongly associated with increased expression of cyclin A and cyclin B1. This suggests combined impairment of a complex cell-cycle control network involving the p27, the P53 pathway, and the Rb1 pathway, which exerts a cooperative effect resulting in enhanced tumor cell proliferation. It could be, therefore, hypothesized that the concurrent alteration of p27/p53/Rb/p16 status may be an important promoting factor of increased tumor cell proliferation in de novo DLBCL.
Acknowledgment: The authors are grateful to Antigoni Christodoulou for her excellent technical assistance.

\section{REFERENCES}

1. Gillet CE, Barnes DM. Cell cycle. J Clin Pathol 1998;51:310-6.

2. McDonald RE, El-Deiry WS. Cell cycle control as a basis for cancer drug development. Int J Oncol 2000;16:871-86.

3. Prives C, Hall P. The p53 pathway. J Pathol 1999;187:112-26.

4. Moller MB. P27 in cell cycle control and cancer. Leuk Lymphoma 2000;39:19-27.

5. Lloyd RV, Erickson LA, Jin L, Kulig E, Qian X, Cheville JC, Scheithauer BW. P27/KIP1: a multifunctional cyclindependent kinase inhibitor with prognostic significance in human cancers. Am J Pathol 1999;154:313-23.

6. Sherr CJ. The Pezcoller lecture: cancer cell cycles revisited. Cancer Res 2000;60:3689-95.

7. Harris NL, Jaffe ES, Stein H, Bankes PM, Chay JK, Cleary ML, Pelsol G, De wolf-Peeters G, Issacson PG, Knowles DM, Mason DY, Muller-Hermenlink HK, Pileri SA, Piris MA, Ralfkiaer E, Warnke RA. Revised European-American classification of lymphoid neoplasms. A proposal from the International Lymphoma Study Group. Blood 1994;84:1361-92.

8. Chan WC, Armitage JO, Gascoyne R, Connors J, Close P, Jacobs P, Norton A, Lister TA, Pedrinis E, Cavalli F, Berger F, Coiffier B, Ho F, Liang R, Schauer A, Hiddemann W, Diebold J, MacLennan KA, Mueller-Hermelink HK, Nathwani BN, Weisenburger DD, Harris NL, Anderson JR, Roy P. A clinical evaluation of the international Lymphoma Study Group classification of non-Hodgkin's lymphoma. Blood 1997;89: 3909-18.

9. Alizadeh AA, Eisen MB, Davis RE, Ma C, Lossos IS, Rosenwald A, Boldrick JC, Sabet H, Tran T, Yu X, Powell JI, Yang L, Marti GE, Moore T, Hudson J, Lu L, Lewis DB, Tibshirani R, Sherlock G, Chan WC, Greiner TC, Weisenburger DD, Armitage JD, Warnke R, Levy R, Wilson W, Grever MR, Byrd JC, Botstein D, Brown PO, Staudt LM. Distinct types of diffuse large B-cell lymphoma identified by gene expression profiling. Nature 2000;403:503-11.

10. Moller MB, Nielsen O, Pedersen NT. Oncoprotein MDM2 overexpression is associated with poor prognosis in distinct nonHodgkin's lymphoma entities. Mod Pathol 1999;12:1010-6.

11. Chilosi M, Doglionni C, Magalini A, Inghirarni G, Krampera M, Nadali G, Rahal D, Pedron S, Benedetti A, Scardoni M, Macri E, Lastani M, Menestrina F, Pizzolo G, Scarpa A. p21/ WAF1 cyclin-kinase inhibitor expression in no-Hodgkin's lymphomas: a potential marker of p53 tumor-suppressor gene function. Blood 1996;88:4012-20.

12. Grierson AJ, Hodgkins MA, Hancock BW, Goepel JR, Royds J, Goyus $\mathrm{MH}$. Investigation of the $\mathrm{Rb}-1$ tumour suppressor gene in a United Kingdom series of non-Hodgkin's lymphomas. Leuk Lymphoma 1996;23:353-63.

13. Hangaishi A, Ogawa S, Imamura N, Miyawaki S, Miura $Y$, Uike N, Shimazaki C, Emi N, Takeyama K, Hirosawa S, Kamada N, Kobayashi Y, Takemoto Y, Kitani T, Toyama K, Ohtake S, Yazaki Y, Ueda R, Hirai H. Inactivation of multiple tumor-suppressor genes involved in negative regulation of the cell cycle, MTS1/p16(INK4A)/CDKN2, MTS2/p15 (INK4B), p53 and Rb genes in primary lymphoid malignancies. Blood 1996;87:4949-58.

14. Tzardi M, Kouvidou C, Panayiotides J, Stefanaki S, Koutsoubi K, Zois E, Rontogianni D, Eliopoulos G, Delides G, Kanavaros P. Expression of p53, mdm2 and p21/waf-1 proteins in nonHodgkin's lymphomas. J Clin Pathol 1996;49:M278-83.

15. Chiarle R, Budel LM, Skolnik J, Frizzera C, Chilosi M, Corato A, Pizzolo G, Magidson J, Montagnoli A, Pagano M, Maes B, 
De Wolf-Peeters, Inghirami G. Increased proteasome degradation of cyclin-dependent kinase inhibitor p27 is associated with a decreased overall survival in mantle cell lymphoma. Blood 2000;95:619-26.

16. Sanchez-Beato M, Saez AI, Martinez-Montero JC, Sol-Mateo M, Sanchez-Verde L, Villuendas R, Troncone G, Piris MA. Cyclin-dependent kinase inhibitor p27/KIP1 in lymphoid tissue. P27/KIP1 expression is inversely proportional to the proliferative index. Am J Pathol 1997;151:151-60.

17. Villuendas R, Pezzella F, Gatter K, Algara P, Sanchez-Beato M, Martinez P, Martinez JG, Munoz K, Garcia P, Sanchez L, Kocialkowsky S, Campo E, Orradre JL, Piris MA. p21 WAF1/CIP1 and mdm2 expression in non-Hodgkin's lymphoma and their relationship to p53 status: a p53+, mdm2-, p21immunophenotype associated with missense p53 mutations. J Pathol 1997;181:51-61.

18. Kiviniemi M, Sauroja I, Rajamaki A, Punnonen K, Soderstrom KO, Salminen E. Cell cycle regulators p27 and pRb in lymphomas-correlation with histology and proliferative activity. Br J Cancer 2000;83:1161-7.

19. Geradts J, Andriko JW, Abbondanzo SL. Loss of tumor suppressor p16 gene expression in high grade but not in low grade non-Hodgkin's lymphomas. Am J Clin Pathol 1998; 109:669-74.

20. Pinyol M, Cobo F, Bea S, Jares P, Nayach I, Fernandez PL, Montserrat E, Cardesa A, Campo E. P16 INKA4 gene inactivation by deletions, mutations, and hypermethylation is associated with transformed and aggressive variants of nonHodgkin's lymphomas. Blood 1998;91:2977-84.

21. Villuendas R, Sanchez-Beato M, Martinez JC, Saez A, Martinez-Delgado B, Garcia J, Sol-Mateo M, Sanchez-Verde L, Beniter J, Martinez P, Piris M. Loss of p16/INK4A protein expression in non-Hodgkin's lymphomas is a frequent finding associated with tumor progression. Am J Pathol 1998; 153:887-97.

22. Baur AS, Shaw P, Burri N, Delacretaz F, Bosman FT, Chaubert P. Frequent methylation silencing of p15 (INK4b) (MTS1) and p16 (INK4a) (MTS2) in B and T-cell lymphomas. Blood 1999;94:1773-81.

23. Pabst T, Peters UR, Tinguely M, Scwaller J, Tschan M, Aebi S, Vonlanthev S, Borisch B, Betticher DC, Zimmerman A, Tobler A, Fey MF. Divergent expression of cyclin-dependent kinase inhibitors (Cki) and P14Arf/p16beta in nonHodgkin's lymphomas and chronic lymphocytic leukemia. Leuk Lymphoma 2000;37:639-48.

24. Moller MB, Ino Y, Gerdes AM, Skjodt K, Louis DN, Pedersen NT. Aberrations of the $\mathrm{p} 53$ pathway components $\mathrm{p} 53, \mathrm{mdm} 2$ and CDKN2A appear independent in diffuse large B cell lymphoma. Leukemia 1999;13:453-9.

25. Moller MB, Skjodt K, Mortensen LS, Pedersen NT. Clinical significance of cyclin-dependent kinase inhibitor p27Kipl expression and proliferation in non-Hodgkin's lymphoma: independent prognostic value of p27Kipl. Br J Haematol 1999;105:730-6.

26. Sanchez-Beato M, Camacho FI, Martinez-Montero JC, Saez AI, Villuendas R, Sanchez-Verde L, Garcia JF, Piris MA. Anomalous high p27/KIP1 expression in a subset of aggressive B-cell lymphomas is associated with cyclin D3 overexpression and P27/KIP1-cyclin D3 colocalization in tumor cells. Blood 1999;94:765-72.

27. Wolowiec D, Berger F, Ffrench P, Bryon PA, Ffrench M. CDK1 and cyclin A expression is linked to cell proliferation and associated with prognosis in non-Hodgkin's lymphomas. Leuk Lymphoma 1999;35:147-57.

28. Weide R, Tiemann M, Pfluger KH. Altered expression of retinoblastoma gene product in human high-grade nonHodgkin's lymphomas. Leukemia 1994;8:97-101.

29. Moller MB, Kania PW, Ino Y, Gerdes AM, Nielsen O, Louis DN, Skjodt K, Pedersen NT. Frequent disruption of the RB1 pathway in diffuse large B cell lymphoma: prognostic significance of E2F-1 and p161NK4A. Leukemia 2000;14:898-904.

30. Pinyol M, Hernandez L, Martinez A, Cobo F, Hernandez S, Bea S, Lopez-Guillermo A, Nayach I, Palacin A, Nadal A, Fernandez PL, Montserrat E, Cardesa A, Campo E. INK4a/ ARF locus alteration in human non-Hodgkin's lymphomas mainly occur in tumors with wild-type p53 gene. Am J Pathol 2000;156:1987-96.

31. Stefanaki K, Tzardi M, Kouvidou C, Rontogianni D, Bolioti S, Chaniotis V, Vlychou M, Delides G, Kanavaros P. Expression of p53, mdm2, p21, Rb, Ki67, bcl2 and bax proteins in lymphomas of the mucosa-associated lymphoid tissue. Anticancer Res 1998;18:2403-8.

32. Gronbaek K, de Nully Brown P, Moller MB, Nedergaard T, Ralfkiaer E, Moller P, Zeuthen J, Guldberg P. Concurrent disruption of p16INK4a and the ARF-p53 pathway predicts poor prognosis in aggressive non-Hodgkin's lymphoma. Leukemia 2000;14:1727-35.

33. Sanchez E, Chacon I, Plaza MM, Munoz E, Cruz B, Martinez B, Lopez L, Martinez-Montero JC, Orradre JL, Saez AI, Garcia JF, Piris M. Clinical outcome in diffuse large B-cell lymphoma is dependent on the relationship between different cell-cycle regulator proteins. J Clin Oncol 1998;16:1931-9.

34. Erlanson M, Portin C, Linderholm B, Lindh J, Roos G, Landberg G. Expression of cyclin E and the cyclin-dependent kinase inhibitor p27 in malignant lymphomas-prognostic implications. Blood 1998;92:770-7.

35. Moller MB, Gerdes AM, Skjodt K, Mortensen LS, Pedersen NT. Disrupted p53 function as predictor of treatment failure and poor prognosis in B- and T-cell non-Hodgkin's lymphoma. Clin Cancer Res 1999;5:1085-91.

36. Saez A, Sanchez E, Sanchez-Beato M, Cruz MA, Chacon I, Munoz E, Camacho FI, Martinez-Montero JC, Mollejo M, Garcia JF, Piris MA. p27/KIP1 is abnormally expressed in diffuse large B-cell lymphoma and is associated with an adverse clinical outcome. Br J Cancer 1999;80:1427-34.

37. Stokke T, Galteland E, Holte H, Smedshammer L, Suo Z, Smeland EB, Borresen-Dale AL, DeAngelis P, Steen HB. Oncogenic aberrations in the p53 pathway are associated with a high $\mathrm{S}$ phase fraction and poor survival in B-cell nonHodgkin's lymphomas. Int J Cancer 2000;89:313-24.

38. Martinez JC, Piris MA, Sanchez-Beato M, Villuendas R, Orradre JL, Algara P, Sanchez-Verde L, Martinez P. Retinoblastoma $(\mathrm{Rb})$ gene product expression in lymphomas. Correlation with Ki67 growth fraction. J Pathol 1993;169:405-12.

39. Drexler P. Review of alterations of the cyclin-dependent kinase inhibitor INK4 family genes p15, p16, p18 and p19 in human leukemia-lymphoma cells. Leukemia 1998;12:84559.

40. Fero ML, Randel E, Gurley KE, Roberts JM, Kemp CJ. The murine gene p27Kip1 is haplo-insufficient for tumour suppression. Nature 1998;396:77-80.

41. Park MS, Rosai J, Nguyen HT, Capodieci P, Cordon-Cardo C, Koff A. p27 and Rb are on overlapping pathways suppressing tumorigenesis in mice. Proc Natl Acad Sci U S A 1999;96: 6382-7.

42. Hirano K, Minamoto T. Altered expression of p53 and p27 proteins, alone or combined, as a predictor of metastatic potential in early invasive carcinoma of colon and rectum-a comparative clinicopathologic and molecular analysis. Cancer Detect Prev 2000;24:342-55.

43. Kanavaros P, Stefanaki K, Vlachonikolis J, Eliopoulos G, Kakolyris S, Rontogianni D, Gorgoulis V, Georgoulias V. Expression of p53, p21/waf-1, bcl-2, bax, Rb and Ki-67 proteins in Hodgkin's lymphomas. Histol Histopathol 2000;15:445-53.

44. Kanavaros P, Bai M, Stefanaki K, Poussias G, Zioga E, Rontogianni D, Gorgoulis V, Agnantis J. Immunohistochemical expression of p53, mdm2, p21/waf-1, Rb, p16, cyclin D1, 
Ki-67, cyclin A and cyclin B1 proteins and apoptotic index in T-cell lymphomas. Histol Histopathol 2001;16:377-86.

45. Kinoshita I, Dosaka-Akita H, Mishina T, Akie K, Nishi M, Hiroumi H, Hommura F, Kawakami Y. Altered p16INKA4 and retinoblastoma protein status in non-small cell lung cancer: potential synergistic effect with altered p53 protein in proliferative activity. Cancer Res 1996;56:5557-62.

46. Gorgoulis VG, Zacharatos P, Kotsinas A, Mariatos G, Liloglou T, Vogiatzi T, Foukas P, Rassidakis G, Garinis G, Ioannides T, Bramis J, Michail PO, Field JK. Altered expression of the cell cycle regulatory molecules pRb, p53 and MDM2 exert a synergetic effect on tumor growth and chromosomal instability in non-small cell lung carcinomas (NSCLCs). Mol Med 2000;6(3):208-37.

47. Tsai KY, Hu Y, MacLeod KF, Crowley D, Yamasaki L, Jacks T. Mutation of E2F-1 suppresses apoptosis and inappropriate S phase entry and extends survival of Rb-deficient mouse embryos. Mol Cell 1998;2:293-304.

48. Pan H, Yin C, Dyson NJ, Harlow E, Yamasaki L, Dyke TV. Key roles for E2F-1 in signaling p53-dependent apoptosis and in cell division within developing tumors. Mol Cell 1998;2:283-92.

49. Bates S, Phillips AC, Clark PA, Stott F, Petters G, Ludwig RL, Vousden KH. P14ARF links the tumour suppressors RB and p53. Nature 1998;395:24-5.

50. Zerfass-Thome K, Schultze A, Zwerschkew W, Vogt B, Helin K, Bartek J, Henglein B, Jansen-Durr P. P27/KIP1 blocks cyclin E-dependent transactivation of cyclin A gene expression Mol Cell Biol 1997;17:407-15.

51. Sheaf RJ, Groudine M, Gordon M, Roberts JM, Clurman BE. Cyclin E-CDK2 is a regulator of p27/KIP1. Genes Dev 1997; 11:1464-78. 